\title{
Effect of experimental design on responses to 2 concentrations of metabolizable protein in multiparous dairy cows
}

\author{
G. I. Zanton* \\ USDA Agricultural Research Service, US Dairy Forage Research Center, Madison, WI 53706
}

\begin{abstract}
The objective of this research was to characterize the implications of changing between diets formulated to be adequate (ADMP) or low (LOMP) in metabolizable protein in a Latin square (LSq) design or of feeding the same diets continuously in a randomized complete block experimental design (RCBD). Fifty-four multiparous early-lactation cows (initial average $\pm \mathrm{SD}$; parity $2.8 \pm$ $0.9,85.8 \pm 31 \mathrm{~d}$ in milk, $715 \pm 63 \mathrm{~kg}$ of body weight, $29.1 \pm 2.7 \mathrm{~kg}$ of dry matter intake/d, and $57.7 \pm 5.7$ $\mathrm{kg}$ of milk yield/d) were blocked by parity and days in milk and were then randomly assigned to experimental design, with 16 cows assigned to LSq and 38 cows assigned to RCBD. Cows within blocks in LSq were randomly assigned to sequence in a 4-sequence, 4-period, 2-treatment LSq balanced for the effects of previous treatment carryover. Cows within blocks in RCBD were randomly assigned to dietary treatment, which was fed over the same four 28-d periods as the cows in LSq. Treatment diets were formulated to be similar in composition with the exception of exchanging an equal quantity of expeller soybean meal from ADMP (16.5\% crude protein; $28.4 \%$ ash-free, amylase-treated neutral detergent fiber organic matter) for soybean hulls in LOMP (14.6\% crude protein; $31.1 \%$ ash-free, amylasetreated neutral detergent fiber organic matter). Cows were individually fed treatment diets in a tiestall barn once daily for ad libitum consumption, milked 3 times daily, and administered recombinant bovine somatotropin every $14 \mathrm{~d}$. Milk yield and feed offered and refused were measured daily; BW was recorded on 2 consecutive days each week; milk composition was measured at 6 consecutive milkings each week; and spot samples of feces, urine, and blood were collected during the last week of each period and a covariate period. Experimental designs were analyzed separately using results from wk 4 of each period with mixed effects modeling. Dry matter intake and milk fat yield were not affected by
\end{abstract}

Received September 20, 2018.

Accepted February 2, 2019.

*Corresponding author: geoffrey.zanton@ars.usda.gov diet in either design, whereas milk and protein yields were greater for cows fed ADMP in both designs. Milk fat and protein percentage responses and milk energy output inferences were different between designs. Milk fat yield and percentage responses were affected by previous treatment carryover in LSq. Metabolic and digestibility inferences were very similar between designs. Under the conditions of this experiment, inferences on $\mathrm{N}$ metabolism and the majority of production measurements were not affected by experimental design, with the principal exceptions of milk fat and protein percentage and milk energy output.

Key words: metabolizable protein, milk production, experimental design

\section{INTRODUCTION}

Providing optimum levels of dietary protein is important to enhance productivity while increasing $\mathrm{N}$ efficiency and reducing $\mathrm{N}$ excretion to the environment (Huhtanen and Hristov, 2009; Powell et al., 2010). To enable dairy farmers and their consultants to efficiently and cost effectively meet these nutritional requirements of the dairy cow, recommendations are made based on the results of designed experiments. For the inferences from these experiments to be valid in an on-farm setting, the conditions of the experiment should represent the conditions in which the data will be used. Frequently, nutritional experiments are conducted in such a way that cows receive several treatment diets for short periods of time compared with what might be expected in practice. In particular, these shorter durations are used when an animal may change between dietary treatments as part of a changeover experimental design such as a switchback or Latin square (Lucas, 1960). The extent to which these design considerations affect the inferences of experiments has been of interest for some time (Cochran et al., 1941) and has been the subject of recent research relevant to protein and AA feeding (Benefield et al., 2009; Lee et al., 2015) or analyzed using literature data in meta-analyses (Huhtanen and Hetta, 2012; Zanton, 2016). Two principal questions are evident when using short-term experiments to estimate 
responses that would be applied to long-term feeding situations: is enough time allowed so that the animal can adequately adapt to the new treatment, and does the nutritional history of the animal affect the results (Ferrell et al., 1986) because carry-over effects of previous treatments are different? This has been especially emphasized with respect to dietary protein because of the possibility of changing the dynamics of body protein degradation and synthesis by relying on body protein reserves (Paquay et al., 1972) and particularly for some $\mathrm{AA}$, which have sizable storage pools that need to reach equilibrium to the new AA status (e.g., histidine; Giallongo et al., 2016). However, recent meta-analyses of responses in lactating dairy cow nutrition experiments have found that changeover studies and continuous studies result in similar inferences except when treatments are extreme, in which case the changeover design underestimated the response observed in the continuous study (Huhtanen and Hetta, 2012; Zanton, 2016). Literature analyses are very valuable to address the implications of experimental design across a wide range of dietary conditions; however, design-specific differences in animal or dietary characteristics and frequently experimental objectives and sampling intensity were evident in both meta-analyses. Furthermore, no direct comparison of continuous and changeover designs in lactating dairy cows was available that was not otherwise confounded by differences in objective or sampling intensity (Zanton, 2016). Therefore, the objective of this study was to evaluate the effects of 2 levels of MP on lactation performance, digestibility, and metabolism when dairy cows are fed diets continuously or according to a changeover experimental design. The hypothesis was that inference about treatment effects would be independent of experimental design (changeover or continuous) under conditions in which MP concentration was predicted to be either adequate or low.

\section{MATERIALS AND METHODS}

\section{Cows, Experimental Designs, and Diets}

All experimental procedures involving the use of animals were approved by the University of Wisconsin Institutional Animal Care and Use Committee (protocol no. A005043). To meet the objective of this research, 54 early-lactation multiparous Holstein cows were selected from the research herd at the Dairy Forage Research Center dairy farm in Prairie du Sac, Wisconsin. Cows were in lactation 2 to 5 and were 43 to 142 DIM at the beginning of the covariate period; summary descriptions of the cows collected before the initiation of the study during the covariate period are reported in Table 1 . The study consisted of a 14-d covariate period followed by a 112-d experimental period during which cows were fed their treatment diets either continuously according to a randomized complete block design (RCBD) or according to a replicated 4-period, 4-sequence, 2-treatment Latin square design (LSq) with 28-d periods that was balanced for carry-over of previous treatment (design 4.4.13 in Jones and Kenward, 2003). Cows were balanced according to lactation number and blocked by DIM ( $\mathrm{n}=4$ : starting DIM <60, 61-100, 101-120, and $>121)$ and then randomly allocated to $\operatorname{RCBD}(\mathrm{n}=38)$ or LSq $(\mathrm{n}=16)$. Cows in either design were randomly distributed throughout the barn, and management and experimental procedures were conducted identically irrespective of design, with the only difference being that cows in LSq could change diets between periods.

Cows were individually fed once daily and housed in cross-ventilated tiestalls during the 4-mo study with feed provided and water available for ad libitum consumption and recombinant bovine somatotropin (500 $\mathrm{mg}$ of Posilac, Elanco Animal Health, Greenfield, IN) administration every $14 \mathrm{~d}$ (d 12 and 26 of each 28 -d period). Feed was offered between approximately 0700 and 0800 $\mathrm{h}$ at between 105 and $110 \%$ of expected consumption, and feed refusals were collected at approximately 0500 h. Cows were milked 3 times daily at approximately 0400, 1100, and $1900 \mathrm{~h}$. For $14 \mathrm{~d}$ before the initiation of treatment diet feeding, cows were continued on the common herd diet, after which time the treatment diet feeding commenced (Table 2). Treatment diets were formulated to promote differences in primary production measurements such as milk production and to have these differences be as extreme as possible within the context of changing dietary protein at levels considered commercially practical (Hristov et al., 2018). To this end, diets were formulated that were predicted to be adequate in MP (ADMP; based on NRC, 2001) or to be low in MP (LOMP) by exchanging expellers soybean meal for soybean hulls, resulting in diets that were 16.5 and $14.6 \% \mathrm{CP}$, respectively (Table 2). As-fed composition was adjusted weekly based on DM measurements to maintain dietary ingredient and $\mathrm{CP}$ concentration (Supplemental Figure S1, https://doi .org/10.3168/jds.2018-15730).

\section{Sampling and Laboratory Analysis}

Temperature and humidity measurements were taken every 15 min throughout the study at 2 locations in the barn using an EL-USB-2-LCD data logger (Lascar Electronics Inc., Erie, PA) and temperature-humidity index was calculated (NRC, 1971). Samples of forages, TMR, high-moisture corn, and orts were collected daily, composited weekly, and stored at $-20^{\circ} \mathrm{C}$ until analysis. Samples of dried distiller grains with solubles, roasted 
Table 1. Covariate period characteristics of cows assigned to the Latin square design (LSq; $\mathrm{n}=14$ ) or randomized complete block design $(\mathrm{RCBD} ; \mathrm{n}=32)^{1}$

\begin{tabular}{lccccc}
\hline & \multicolumn{2}{c}{ LSq } & & \multicolumn{2}{c}{ RCBD } \\
\cline { 2 - 3 } \cline { 5 - 6 } Item & Average & SD & & Average & SD \\
\hline Lactation no. & 2.6 & 0.93 & & 2.9 & 0.94 \\
Age, mo & 46.9 & 12.08 & & 51.2 & 12.33 \\
DIM & 89.7 & 33.38 & & 84.1 & 30.10 \\
BW, kg & 704 & 73 & & 720 & 59 \\
DMI, kg/d & 29.0 & 3.02 & & 29.1 & 2.58 \\
Milk, kg/d & 56.6 & 3.67 & & 58.1 & 6.39 \\
Protein, $\mathrm{kg} / \mathrm{d}$ & 1.56 & 0.126 & & 1.56 & 0.141 \\
Protein, \% & 2.75 & 0.149 & & 2.70 & 0.183 \\
Fat, $\mathrm{kg} / \mathrm{d}$ & 2.17 & 0.297 & & 2.21 & 0.263 \\
Fat, \% & 3.83 & 0.359 & & 3.81 & 0.384 \\
Lactose, kg/d & 2.84 & 0.203 & & 2.86 & 0.307 \\
Lactose, \% & 5.02 & 0.134 & & 4.93 & 0.161 \\
MUN, g & 7.08 & 0.736 & & 7.11 & 1.193 \\
MUN, mg/dL & 12.54 & 1.183 & & 12.24 & 1.827 \\
NE, Mcal & 40.2 & 3.90 & & 40.6 & 3.95 \\
NE $/$ DMI, Mcal/kg & 1.4 & 0.12 & & 1.4 & 0.16 \\
Milk protein N/N intake, g/100 g & 30.8 & 1.90 & & 30.9 & 2.68 \\
\hline
\end{tabular}

${ }^{1}$ Measurements were taken before treatment diet feeding on cows that completed the experiment.

soybeans, canola meal, soybean hulls, and expeller soybean meal were collected once weekly and stored at room temperature. Feed, TMR, and ort samples were thawed at room temperature, dried at $55^{\circ} \mathrm{C}$ for approximately $72 \mathrm{~h}$, and ground through a 1-mm screen (Wiley mill, Arthur H. Thomas Co., Philadelphia, PA). Weekly feed samples were analyzed for DM, NDF, and starch by Dairyland Laboratories Inc. (Arcadia, WI) to monitor compositional analysis (Supplemental Figure S1; https://doi.org/10.3168/jds.2018-15730). Feed, TMR, and orts for the sampling weeks were analyzed for DM (method 934.01; AOAC, 1990), ash (method 938.08; AOAC, 1990), N (Leco N Analyzer, Leco Corp., St. Joseph, MI), and NDF determined with $\alpha$-amylase, $\mathrm{Na}_{2} \mathrm{SO}_{3}$, exclusive of ash ( $\left.\mathbf{a N D F} \mathbf{F}_{\mathbf{O M}}\right)$ including thermostable $\alpha$-amylase and $\mathrm{Na}_{2} \mathrm{SO}_{3}$ using the Ankom200 Fiber Analyzer (Ankom Technology, Macedon, NY) reported exclusive of residual ash by ashing neutral detergent residue and filter bags after extracting neutral detergent solubles. Indigestible $\mathrm{aNDF}_{\mathrm{OM}}$ was determined in feedstuffs, TMR, and orts by incubating F57 filter bags (25-mm porosity, $5 \times 5 \mathrm{~cm}^{2}$, 350-mg sample; Ankom Technology) for $12 \mathrm{~d}$ in the rumen of 2 cows and analyzing residual sample for $\mathrm{aNDF}_{\mathrm{OM}}$ using the methodology previously described (Lee et al., 2012b). Dietary chemical composition and intake were calculated based on the chemical analysis of the individual ingredients and their contribution to the DM of the TMR where ort composition was assumed to be the same as the TMR offered to mitigate against nonrepresentative sampling. Predictions (NRC, 2001) of $\mathrm{NE}_{\mathrm{L}}, \mathrm{MP}, \mathrm{RDP}$, and RUP were made using feed analyses augmented with tabular values based on a common level of production observed during the covariate period, which would not include changes in DMI and production that would be caused by treatment diet and would therefore represent an estimation of the formulated diet and not an estimation of the consumed diet (Table 2).

Milk yields were recorded at each milking throughout the study. Milk samples for composition were collected at 6 consecutive milkings at 7 -d intervals (d 3-4, 10-11, 17-18, and 24-25 of each consecutive 28-d period for both designs) throughout the entire study and analyzed for fat, protein, lactose, and MUN by near-infrared spectroscopy (AgSource, Verona, WI; Foss FT6000 instrument, Foss Electric, Hillerød, Denmark; method 972.16; AOAC, 1990). Milk component yield was calculated using the concentration of milk components at each milking multiplied by the milk yield at each milking and summed over the sampling day. Milk protein $\mathrm{N}$ was calculated from milk true protein output as milk true protein/6.38, and milk $\mathrm{N}$ output was calculated as the sum of MUN and milk protein N output. Milk $\mathrm{NE}_{\mathrm{L}}$ output was calculated using the formula reported by NRC (2001). On the same days as milk sample collection each week, cows were weighed after the $1900 \mathrm{~h}$ milking.

On d 24 to 25 of each period for both designs, spot samples of urine, feces, and blood were collected beginning at $1200 \mathrm{~h} \mathrm{(d} \mathrm{24)} \mathrm{and} 0000 \mathrm{~h} \mathrm{(d} \mathrm{25;} \mathrm{beginning}$ approximately 4 to $5 \mathrm{~h}$ and 16 to $17 \mathrm{~h}$ after d 24 feeding, respectively). Urine was collected after voluntary urination by the cow or upon mechanical stimulation of the vulva. Urine samples were immediately acidified by diluting $15 \mathrm{~mL}$ of urine with $60 \mathrm{~mL}$ of $0.072 \mathrm{~N} \mathrm{H}_{2} \mathrm{SO}_{4}$ and stored at $-20^{\circ} \mathrm{C}$ until analysis. Urine was thawed 
Table 2. Ingredient and chemical composition for adequate-MP (ADMP) and low-MP (LOMP) diets fed to early-lactation dairy cows according to a Latin square design or a randomized complete block design

\begin{tabular}{|c|c|c|c|}
\hline Item, $\%$ of DM unless noted & Covariate & ADMP & LOMP \\
\hline Corn silage & 25.7 & 37.8 & 37.6 \\
\hline Alfalfa silage & 24.6 & 15.9 & 15.8 \\
\hline Ground high-moisture corn & 26.5 & 19.7 & 19.8 \\
\hline Liquid molasses blend $^{1}$ & - & 2.5 & 2.5 \\
\hline Dried distillers grains plus solubles & 4.1 & 4.0 & 4.0 \\
\hline Roasted soybeans & 7.8 & 5.0 & 5.0 \\
\hline Canola meal & 8.7 & 5.0 & 5.0 \\
\hline Soybean hulls & - & 2.0 & 7.8 \\
\hline Expeller soybean meal ${ }^{2}$ & - & 5.6 & 0.0 \\
\hline Vitamins and minerals ${ }^{3}$ & 2.5 & 2.5 & 2.5 \\
\hline $\mathrm{CP}$ & 17.8 & 16.5 & 14.6 \\
\hline $\mathrm{aNDF}_{\mathrm{OM}}{ }^{4}$ & 28.0 & 28.4 & 31.1 \\
\hline $\operatorname{pdNDF}_{\mathrm{OM}}^{4}$ & 20.5 & 20.9 & 23.6 \\
\hline $\mathrm{iNDF}_{\mathrm{OM}}{ }^{4}$ & 7.5 & 7.5 & 7.5 \\
\hline Forage $\mathrm{NDF}_{\mathrm{OM}}{ }^{4}$ & 17.5 & 20.6 & 20.5 \\
\hline $\mathrm{NE}_{\mathrm{L}},{ }^{5}, \mathrm{Mcal} / \mathrm{kg}$ & 1.59 & 1.57 & 1.54 \\
\hline $\mathrm{MP}^{5}$ & 10.4 & 11.1 & 9.5 \\
\hline $\mathrm{RDP}^{5}$ & 12.2 & 10.1 & 9.6 \\
\hline $\mathrm{RUP}^{5}$ & 5.8 & 6.5 & 5.0 \\
\hline $\mathrm{NE}_{\mathrm{L}}$ balance ${ }_{5}^{5} \mathrm{Mcal} / \mathrm{d}$ & -5.6 & -6.3 & -7.2 \\
\hline MP balance, ${ }^{5} \mathrm{~g} / \mathrm{d}$ & -319 & -107 & -573 \\
\hline RDP balance, ${ }^{5} \mathrm{~g} / \mathrm{d}$ & 668 & 64 & -44 \\
\hline
\end{tabular}

${ }^{1}$ Formulated to contain (as-fed basis) $73 \%$ cane molasses, $17 \%$ water, and $10 \%$ glycerin. Provided by Westway Feed Products (Tomball, TX). ${ }^{2}$ SoyPlus provided by Landus Cooperative (Ames, IA).

${ }^{3}$ Vitamin and mineral mix contained Ca, $16.7 \%$ of DM; Na, $15.8 \%$ of $\mathrm{DM} ; \mathrm{Cl}, 7.1 \%$ of DM; Mg, $4.6 \%$ of DM; K, $0.6 \%$ of DM; S, $1.0 \%$ of DM; Co, $45 \mathrm{mg} / \mathrm{kg}$; Cu, $554 \mathrm{mg} / \mathrm{kg}$; I, $64 \mathrm{mg} / \mathrm{kg}$; Fe, $830 \mathrm{mg} / \mathrm{kg}$; Mn, 2,776 mg/kg; Se, $16 \mathrm{mg} / \mathrm{kg} ; \mathrm{Zn}, 2,997 \mathrm{mg} / \mathrm{kg}$; monensin, $522 \mathrm{mg} / \mathrm{kg}$; vitamin A, $309 \mathrm{kIU} / \mathrm{kg}$; vitamin D, $62 \mathrm{kIU} / \mathrm{kg}$; vitamin E, 1,454 IU/ $\mathrm{kg}$.

${ }^{4} \mathrm{aNDF}_{\mathrm{OM}}=$ neutral detergent fiber determined with $\alpha$-amylase, $\mathrm{Na}_{2} \mathrm{SO}_{3}$, exclusive of ash. pdNDF $\mathrm{OM}_{\mathrm{M}}=$ potentially digestible aNDF $\mathrm{OM}_{\mathrm{OM}}$ (difference between $\mathrm{aNDF}_{\mathrm{OM}}$ and $\mathrm{iNDF}_{\mathrm{OM}}$ ). $\mathrm{iNDF}_{\mathrm{OM}}=$ indigestible $\mathrm{aNDF}_{\mathrm{OM}}$ based on $12 \mathrm{~d}$ in the rumen.

${ }^{5}$ Predicted from NRC (2001) based on ingredient chemical composition, tabular values, and cow production values recorded during the covariate period.

at room temperature and analyzed for total $\mathrm{N}$ using an $\mathrm{N}$ analyzer (TruMac N, Leco Corp.), urea using a colorimetric method (Broderick and Clayton, 1997), and creatinine using a picric acid method (Oser, 1965) adapted to flow injection analysis (QuickChem 8500, Lachat Instruments, Loveland, CO). Urine output was estimated by assuming that $29 \mathrm{mg}$ of creatinine $/ \mathrm{kg}$ of BW is excreted (Valadares et al., 1999), although the use of this equation may underestimate the variance of urine output and subsequent nutrient excretion based upon it (Tebbe and Weiss, 2018). Output of urinary N and urea was calculated by multiplying the estimated urine output by the concentration of the analyte in the urine.

Fecal samples were collected as the cows defecated or were collected manually from the rectum. These samples were then immediately dried at $55^{\circ} \mathrm{C}$ for approximately $72 \mathrm{~h}$, composited on an equal DM basis, and ground through a 1-mm screen (Wiley mill, Arthur H. Thomas Co.). Ground samples were subsequently analyzed using the procedures previously described for feed. Fecal output was estimated using indigestible $\mathrm{aNDF}_{\mathrm{OM}}$ as an internal marker:

$$
\begin{aligned}
& \text { fecal } \mathrm{DM}= \\
& \mathrm{iNDF}_{\mathrm{OM}} \operatorname{intake}(\mathrm{g} / \mathrm{d})
\end{aligned}
$$

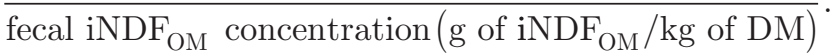

Blood samples were collected in tubes with $\mathrm{K}_{3}$-EDTA as an anticoagulant (Vacuette, Greiner Bio-One North America, Monroe, NC) by venipuncture of the coccygeal artery or vein after the completion of the feces and urine collection. Samples were stored on ice until plasma was separated $\left(1,500 \times g, 4^{\circ} \mathrm{C}, 15 \mathrm{~min}\right)$, aspirated to aliquots, and stored at $-20^{\circ} \mathrm{C}$ until analysis. Individual aliquots were analyzed for glucose (Autokit Glucose, Wako Diagnostics, Mountain View, CA), plasma urea N (PUN; QuantiChrom Urea Assay Kit, BioAssay Systems, Hayward, CA), nonesterified fatty acids (NEFA; NEFA-HR(2), Wako Diagnostics), and insulin (bovine insulin ELISA, Mercodia AB, Uppsala, Sweeden) using commercial kits. Before analyzing for PUN, plasma was deproteinized by combining $0.5 \mathrm{~mL}$ of plasma with $0.5 \mathrm{~mL}$ of $5 \%$ trichloroacetic acid, which was immediately vortexed. This combination sat at room temperature for $10 \mathrm{~min}$, and the supernatant was harvested after $10 \mathrm{~min}$ of centrifuging at 12,000 $\times \mathrm{g}$ at room temperature.

\section{Statistical Analysis}

For consistency between designs and among production, digestibility, and metabolic responses, statistical analysis for treatment effect least squares means was conducted on data for the last week of each period for both designs. The model for the data in LSq was

$$
\begin{aligned}
Y_{i j k l m}= & \mu+\operatorname{Cov}_{i}+S_{j}+T_{k: j}+R_{l} \\
& +P_{m: j k}+c_{i: j}+e_{i j k l m},
\end{aligned}
$$

where $Y_{i j k l m}=$ the dependent variable; $\mu=$ the overall mean; $\operatorname{Cov}_{i}=$ the covariate measurement for cow $i ; S_{j}$ $=$ the fixed effect of square $j$, where $j=1$ to 4 squares (same as DIM blocks, below); $T_{k: j}=$ the fixed effect of treatment $k$ within square $j$, where $k=1,2 ; R_{l}=$ the fixed effect of previous treatment $l$, where $l=1,2 ; P_{m: j k}$ $=$ the fixed effect of period $m$ within square $j$ and treat- 
ment $k$, where $m=1$ to $4 ; c_{i: j}=$ the random effect of cow $i$ within square $j \sim N\left(0, \sigma_{c}^{2}\right)$; and $e_{i j k l m}=$ the random residual $\sim N\left(0, \sigma_{e}^{2}\right)$, where $\sigma_{c}^{2}$ and $\sigma_{e}^{2}$ are the error variances associated with cow and residual effects, respectively.

The statistical model for analysis of RCBD was

$$
Y_{i j k l}=\mu+\operatorname{Cov}_{i}+B_{j}+T_{k: j}+W_{l: j k}+c_{i: j k}+e_{i j k l},
$$

where $Y_{i j k l}=$ the dependent variable; $\mu=$ the overall mean; $\operatorname{Cov}_{i}=$ the covariate measurement for cow $i ; B_{j}$ $=$ the fixed effect of block $j$, where $j=1$ to $4 ; T_{k: j}=$ the fixed effect of treatment $k$ within block $j$, where $k=1$, $2 ; W_{l: j k}=$ the fixed effect of week $l$ within block $j$ and treatment $k$, where $l=4,8,12$, or $16 \mathrm{wk} ; c_{i: j k}=$ the random effect of subject $i$ within block $j$ and treatment $k \sim N\left(0, \sigma_{c}^{2}\right)$; and $e_{i j k l}=$ the random residual $\sim N\left(0, \sigma_{e}^{2}\right)$.

Statistical analysis was conducted using the mixed procedure of SAS (SAS Institute, 2013). For comparison between designs, for least squares means calculation, the value for $\operatorname{Cov}_{i}$ was based on the overall average response measured during the covariate period and not based on the average for each design. Treatment and treatment $\times$ week interaction effects and tests were calculated from the above reduced models within PROC MIXED. Denominator degrees of freedom and small-sample corrections to the standard errors were conducted using the Kenward-Roger adjustment. Autocorrelation between repeated measures in the RCBD was modeled using the first-order auto-regressive covariance structure. To compare the evidence resulting from the different designs, $t$-scores of the treatment differences were calculated. From these, a concordance correlation coefficient (Lin, 1989) was calculated using the epiR package in $\mathrm{R}$ ( $\mathrm{R}$ Core Team, 2015). Differences were considered significant when $P<0.05$.

\section{RESULTS AND DISCUSSION}

\section{General Considerations}

The cows enrolled in this study were all multiparous and in early to mid lactation. Throughout the course of the experiment, 8 cows had to be removed for various reasons that did not appear to be related to dietary treatment or experimental design, and the responses for these cows were not used in any analysis. The remaining 46 cows averaged $( \pm$ SD) $29 \pm 2.69 \mathrm{~kg}$ of DMI/d and $57.7 \pm 5.7 \mathrm{~kg}$ of milk yield/d and weighed $715 \pm$ $63 \mathrm{~kg}$ (Table 1). Cows within blocks were randomly assigned to experimental design, and the observed covariate responses were similar between designs. No differences were found in covariate characteristics, so for ease of comparing the responses between the designs, least squares means were covariate adjusted to the common value observed across all cows during the covariate period.

To achieve the objective of this study, diets were designed to promote treatment differences by changing both $\mathrm{CP}$ concentration and degradability to enable the responses in the different designs to be studied as robustly as possible. Within this context, dietary MP was varied by exchanging expeller soybean meal for soybean hulls with all other ingredients formulated to be the same between diets (Table 2). Changing ingredients with these different compositions (Table 3 ) resulted in different $\mathrm{CP}$ and NDF concentrations between diets as expected. Based on pretrial information, the formulation of ADMP was to be adequate in MP; however, using the actual measured parameters, NRC (2001) predicted that this diet resulted in a negative MP balance. Lee et al. (2012b) reported that NRC (2001) underpredicted milk yield in diets that were estimated to be MP deficient, which was observed in this experiment only for LOMP and not ADMP. Cows fed ADMP yielded $55.7 \mathrm{~kg}$ of milk/d with an NRC prediction of $55.0 \mathrm{~kg} / \mathrm{d}$ of MP allowable milk, whereas LOMP cows yielded $53.0 \mathrm{~kg}$ of milk/d with an NRC prediction of $43.5 \mathrm{~kg} / \mathrm{d}$ of MP allowable milk. These observations are consistent with the biological concept of a variable efficiency of MP use for productive purposes (Metcalf et al., 2008; Moraes et al., 2018) compared with the constant efficiency used by the NRC (2001) model. Although the magnitude of the NRC-predicted production differences between diets was not achieved, cows were observed to be sensitive to these levels of dietary MP changes. Therefore, the inferences resulting from the different experimental designs were evaluated when observed treatment responses were significant but not extreme.

At the beginning of any nutritional experiment, including RCBD, the cows' diets need to be changed to meet the objectives of the study. Frequently, whether part of a changeover or a continuous experimental design, an adaptation period is provided to allow the cow to respond to the treatment diet, although the amount of time that is optimal for this to occur is not completely known for most situations. In the literature data used for a previous meta-analysis (Zanton, 2016), cows in changeover designs were adapted to the diet for an average of $13 \mathrm{~d}$, whereas cows in continuous experiments were adapted for an average of $3 \mathrm{~d}$ before data or sample collection began. In this experiment, cows for both designs were fed the treatment diets for a minimum of $24 \mathrm{~d}$ before sample collection began 
Table 3. Ingredient chemical composition (\% of DM unless noted; SD in parentheses)

\begin{tabular}{|c|c|c|c|c|c|c|c|}
\hline Item & $\mathrm{DM},{ }^{1} \%$ as fed & $\mathrm{Ash}^{2}$ & $\mathrm{CP}^{1}$ & $\mathrm{aNDF}_{\mathrm{OM}}^{1,3}$ & $\mathrm{pdNDF}_{\mathrm{OM}}^{2,3}$ & $\mathrm{iNDF}_{\mathrm{OM}}^{2,3}$ & Starch $^{1}$ \\
\hline Alfalfa silage & $43.39(6.08)$ & $11.47(0.70)$ & $23.84(0.91)$ & $37.51(2.34)$ & $17.67(1.21)$ & $16.08(1.68)$ & - \\
\hline Ground high-moisture corn & $71.31(2.51)$ & $1.96(0.08)$ & $8.66(0.39)$ & $8.65(1.91)$ & $6.97(1.77)$ & $0.56(0.65)$ & $70.58(1.18)$ \\
\hline Roasted soybeans ${ }^{4}$ & $96.17(0.38)$ & $5.63(0.14)$ & $37.83(1.62)$ & $19.37(6.24)$ & $25.49(2.07)$ & $3.19(2.07)$ & - \\
\hline Canola meal & $90.37(0.71)$ & $8.78(0.61)$ & $40.44(1.07)$ & $26.67(2.53)$ & $14.78(1.25)$ & $11.54(1.31)$ & - \\
\hline Soybean hulls & $90.38(0.69)$ & $5.65(0.23)$ & $12.23(0.57)$ & $65.30(1.77)$ & $61.19(0.68)$ & $2.45(0.54)$ & - \\
\hline
\end{tabular}

${ }^{1}$ Based on weekly samples.

${ }^{2}$ Based on samples collected during the weeks of sampling.

${ }^{3} \mathrm{aNDF}_{\mathrm{OM}}=$ neutral detergent fiber determined with $\alpha$-amylase, $\mathrm{Na}_{2} \mathrm{SO}_{3}$, exclusive of ash. pdNDF $\mathrm{OM}_{\text {- potentially digestible aNDF }}$. $($ difference between $\mathrm{aNDF}_{\mathrm{OM}}$ and $\left.\mathrm{iNDF}_{\mathrm{OM}}\right) . \mathrm{iNDF}_{\mathrm{OM}}=$ indigestible $\mathrm{aNDF}_{\mathrm{OM}}$ based on $12 \mathrm{~d}$ in the rumen.

${ }^{4}$ Roasted to a protein dispersibility index of 9 to 11 (Wu and Satter, 2000).

for analyzing the responses due to dietary differences. Weekly production responses are shown graphically for illustrating time-course responses to treatments.

\section{Production Responses}

Body weight and BW change were not affected by treatment diets (Table 4). The diets in this study generally resulted in DMI that was initially higher than that observed during the covariate period and declined throughout the study, although the contributions of DIM cannot be separated from the experimental periods (Figure 1). This treatment $\times$ time interaction in DMI is an important response that could have practical relevance on dairy farms and for the interpretation of experiments. However, this type of response is not observable in experiments designed as LSq, and this limitation must be considered with respect to the study objectives when choosing an experimental design. Cows that were continuously fed ADMP in RCBD were observed to have the lowest DMI throughout most of the study (Figure 1), although this observation was not statistically significant $(P=0.122$; Table 4$)$. Many studies (Lee et al., 2012a; Giallongo et al., 2016; Barros et al., 2017) and meta-analyses (Huhtanen and Hetta, 2012; Zanton, 2016) have shown that reducing dietary $\mathrm{CP}$ concentration leads to reduced DMI, although exceptions to this observation are also frequent $(\mathrm{Wu}$ and Satter, 2000; Colmenero and Broderick, 2006; Lee et al., 2012b). Responses in DMI that are due to hepatic oxidation of propionic acid are very rapid in the postpartum period (Maldini and Allen, 2018), whereas a prolonged timeframe for DMI response was apparently required when dietary protein level was changed in mid lactation (Law et al., 2009). The mechanism by which CP level affects DMI is not well understood. Frequently, a decrease in DMI due to decreasing CP level is attributed to lower ruminal $\mathrm{N}$ status resulting in increased filling effects due to reduced NDF digestibility (Allen, 2000). Lower NDF digestibility was observed for cows fed LOMP in LSq (Table 5), and lower potentially digestible NDF digestibility with LOMP was observed in both designs $(P<0.054)$, although these responses did not result in differences in DMI. Recently, MP status was found to interact with supply of additional MP provided by casein infusion such that increasing MP at higher MP level resulted in reduced DMI, whereas the DMI increased when MP was deficient (Martineau et al., 2016). Ultimately, main effects on DMI were not significant in this study, whether due to competing mechanisms of the action of $\mathrm{CP}$ or due to other factors controlling intake under these conditions. The remaining effects on production, digestibility, and metabolism are therefore interpreted independent of treatment effects on DMI, which confounds many studies in protein nutrition (Huhtanen and Hristov, 2009).

Production of milk and milk components is shown in Table 4, and the time course of production responses for the treatment sequences are shown in Supplemental Figures S2 and S3 (https://doi.org/10.3168/jds.2018 -15730). Irrespective of design, feeding LOMP resulted in lower milk, protein, and lactose yields than feeding ADMP, as was expected. Responses to changing MP level were very rapid for milk yield and milk protein yield, with a large proportion of the ultimate response occurring within $1 \mathrm{wk}$. This is reflected in the close similarity in the least squares means and treatment differences observed for RCBD and LSq. Production and endocrine responses to total diet restriction can be observed in as little as $2 \mathrm{~d}$ (Ferraretto et al., 2014); however, a physiological adaptation to this new level of energy and protein availability may be more prolonged and depend on the stage of lactation (Gross et al., 2011). The time course of production responses to postruminal protein or AA infusion has been observed in several studies to be very rapid, often occurring on the same 
Table 4. Effect of protein concentration ${ }^{1}$ and experimental design on LSM $^{2}$ of DMI, milk yield and composition, and BW in dairy cows fed according to a Latin square design (LSq) or a randomized complete block design (RCBD)

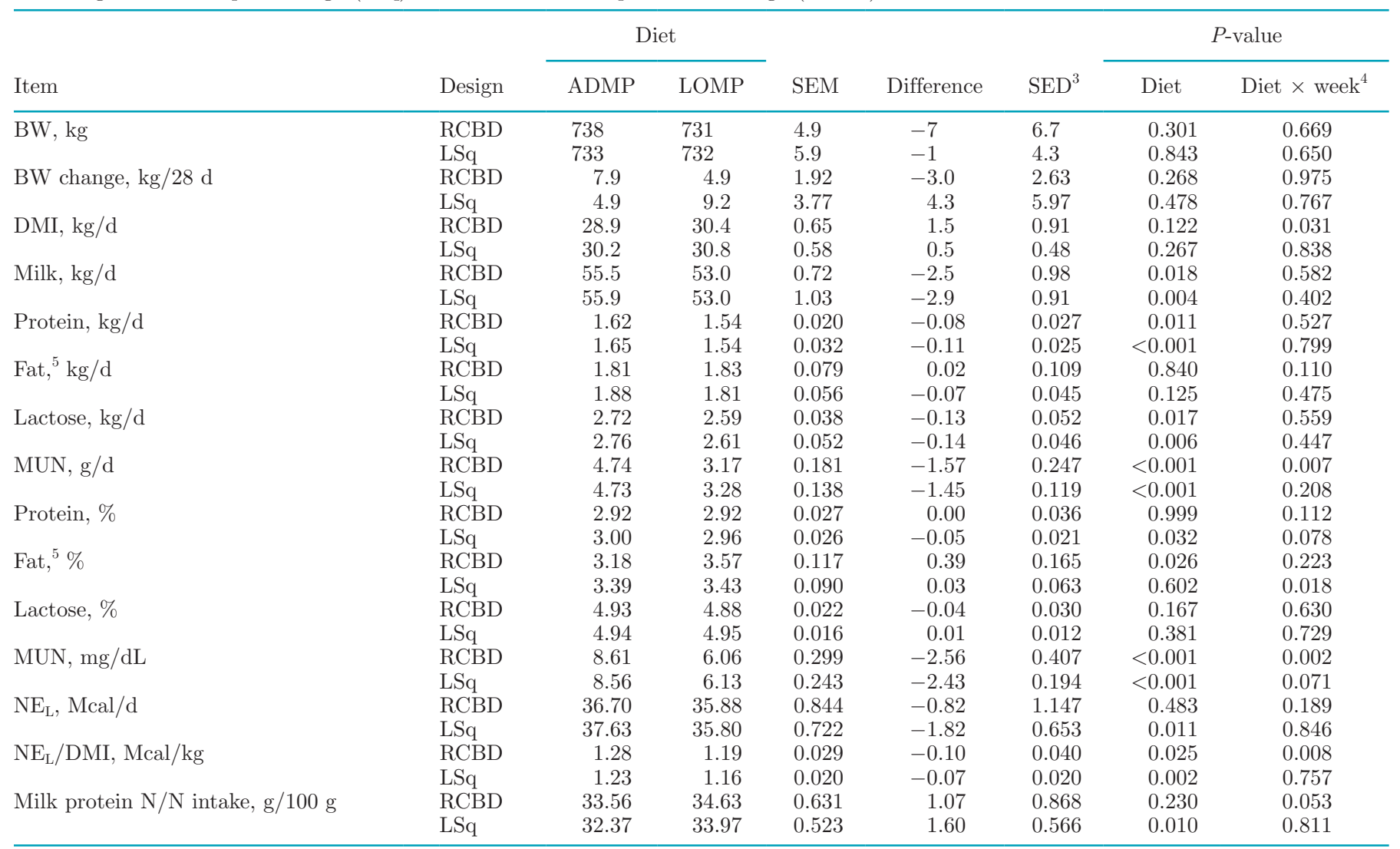

${ }^{1}$ Diets contained either $16.5 \% \mathrm{CP}$ for adequate MP (ADMP) or $14.6 \%$ CP for low MP (LOMP).

${ }^{2}$ Least squares means were covariately adjusted for initial production values measured during the 2 wk before feeding the treatment diets.

${ }^{3}$ Standard error of the difference.

${ }^{4}$ Interaction between diet and week, where week $=4,8,12$, and 16 and is equivalent to periods 1 to 4 in LSq.

${ }^{5}$ Carryover effect of previous treatment was significant $(P<0.05)$ when design was LSq.

day or the days immediately following a change in the infusion rate (Broderick et al., 1970; Whitelaw et al., 1986; Metcalf et al., 1996). In contrast, several studies where cows were fed protected AA have shown more prolonged responses to AA supplementation, such as 2 wk (Benefield et al., 2009) or up to 5 wk (St-Pierre and Sylvester, 2005). Longitudinal studies that include a dietary change have also demonstrated that the duration of time on the new diet for the full response to take effect is around 2 to $5 \mathrm{wk}$ (Wu and Satter, 2000; Law et al., 2009; Gross et al., 2011), although these studies were not designed to evaluate the time course of this response. However, if the treatment is severe enough over a long enough duration, the full response to a new diet may not be observed (Law et al., 2009).

As expected, MUN concentration and output were lower for LOMP than for ADMP, and this response was not affected by design. Lewis (1957) observed that BUN concentration in sheep adapted to changes in dietary carbohydrate degradability or $\mathrm{CP}$ level within approximately $3 \mathrm{~d}$, which was a similar time course that was observed when sheep were turned out on pasture (Annison et al., 1959). Gustafsson and Palmquist (1993) observed rapid diurnal equilibration between serum urea and milk urea in dairy cows. Taken together, these results correspond very closely to the time course response observed after diets were changed between periods in this study (Supplemental Figure S4, https: //doi.org/10.3168/jds.2018-15730) and others (Barros et al., 2017).

After changing diets between periods 1 and 2, cows changing to ADMP had higher milk and milk protein production than cows that were maintained on that diet for periods 1 and 2; the opposite response was observed for cows changing to LOMP. This type of response could be reflective of a compensatory type of productivity resulting from a carryover in productive efficiency (Ferrell et al., 1986). However, these respons- 


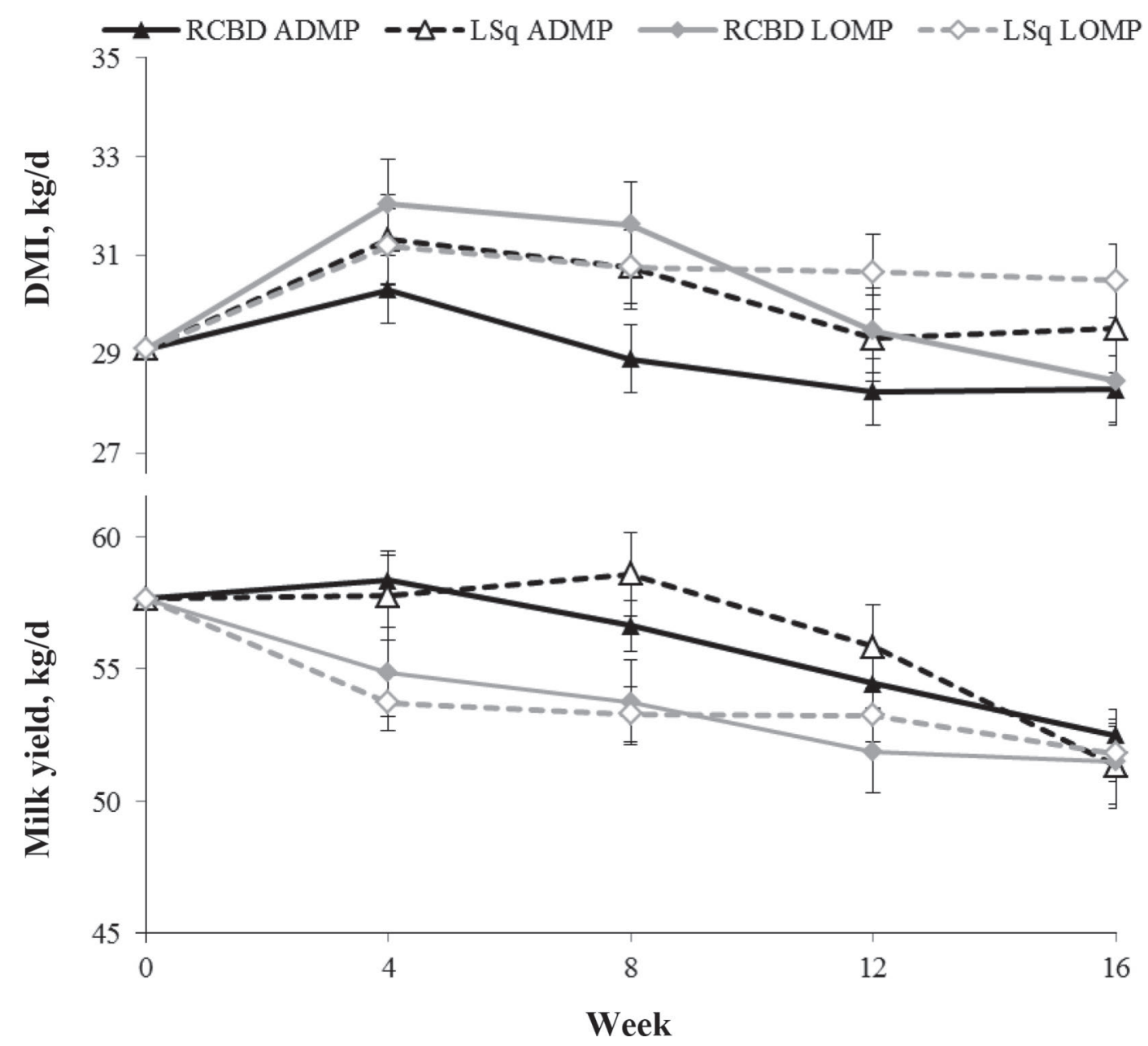

Figure 1. Temporal response to adequate MP (ADMP) and low MP (LOMP) when fed according to randomized complete block design (RCBD) or Latin square design $(\mathrm{LSq})$. When fed in RCBD, there was a tendency for a linear $\times$ treatment interaction $(P<0.09)$ and a significant $(P<0.05)$ quadratic $\times$ treatment interaction for DMI. Treatment $\times$ time interactions were not significant $(P>0.20)$ for milk yield. Error bars are the SEM.

es were not observed with the dietary changes between periods 2 and 3 , and neither the carryover effect of previous treatment nor the treatment $\times$ period interaction were significant for these production responses. These observations are consistent with the results of the 2 recent meta-analyses on the effects of experimental design on milk production when changing $\mathrm{CP}$ within the range of $\mathrm{CP}$ used in this study (Huhtanen and Hetta, 2012; Zanton, 2016).

Yield of milk fat was not affected by dietary treatment (Table 4$)$ in either design $(P>0.125)$. Interestingly, carryover effects of previous treatment were observed due to the higher levels of milk fat production observed when LOMP was the previous treatment than when ADMP was the previous treatment. Rico and Harvatine (2013) evaluated the time course of diet-induced milk fat depression and recovery, and from these results it could be expected that milk fat depression could be induced from altered ruminal biohydrogenation and can recover after 14 to $21 \mathrm{~d}$, where samples in this study were analyzed at d 24 to 25 . The previous treatment effects could alternatively reflect an altered partitioning of fat energy toward milk fat secretion when cows were previously nutritionally restricted due to having consumed LOMP compared with ADMP. Milk fat concentration was likewise affected by previous treatment in LSq, where cows previously fed LOMP had higher milk fat concentration than when previously fed ADMP, although the combination of a previous treatment effect for milk fat yield and no previous treatment effect for milk yield likely created a dilution effect for milk fat concentration. Inferences for milk fat concentration were quite different between designs, with cows fed ADMP in RCBD having reduced milk fat, whereas there was no effect in LSq. A tendency for milk fat concentration to decrease more with increasing $\mathrm{CP}$ in 
Table 5. Effect of protein concentration ${ }^{1}$ and experimental design on LSM $^{2}$ of intake and digestibility in dairy cows fed according to a Latin square design (LSq) or a randomized complete block design (RCBD)

\begin{tabular}{|c|c|c|c|c|c|c|c|c|}
\hline \multirow[b]{2}{*}{ Item } & \multirow[b]{2}{*}{ Design } & \multicolumn{2}{|c|}{ Diet } & \multirow[b]{2}{*}{ SEM } & \multirow[b]{2}{*}{ Difference } & \multirow[b]{2}{*}{$\mathrm{SED}^{3}$} & \multicolumn{2}{|c|}{$P$-value } \\
\hline & & ADMP & LOMP & & & & Diet & Diet $\times$ week $^{4}$ \\
\hline \multirow[t]{2}{*}{$\mathrm{OM}$} & $\mathrm{RCBD}$ & 27.19 & 28.48 & 0.570 & 1.28 & 0.790 & 0.118 & 0.003 \\
\hline & $\mathrm{LSq}$ & 28.29 & 28.89 & 0.462 & 0.60 & 0.494 & 0.239 & 0.943 \\
\hline \multirow[t]{2}{*}{$\mathrm{CP}$} & $\mathrm{RCBD}$ & 4.87 & 4.50 & 0.101 & -0.37 & 0.140 & 0.016 & 0.007 \\
\hline & LSq & 5.08 & 4.57 & 0.078 & -0.50 & 0.083 & $<0.001$ & 0.971 \\
\hline \multirow{2}{*}{$\mathrm{pdNDF}_{\mathrm{OM}}{ }^{5}$} & $\mathrm{RCBD}$ & 6.17 & 7.25 & 0.137 & 1.08 & 0.190 & $<0.001$ & 0.004 \\
\hline & LSq & 6.40 & 7.36 & 0.110 & 0.97 & 0.121 & $<0.001$ & 0.890 \\
\hline \multicolumn{9}{|l|}{ Digestibility, \% } \\
\hline \multirow[t]{2}{*}{$\mathrm{OM}$} & RCBD & 70.26 & 67.11 & 0.554 & -3.15 & 0.796 & $<0.001$ & 0.927 \\
\hline & $\mathrm{LSq}$ & 70.14 & 67.28 & 0.668 & -2.86 & 0.604 & $<0.001$ & 0.200 \\
\hline \multirow[t]{2}{*}{ Apparent CP } & $\mathrm{RCBD}$ & 64.38 & 57.57 & 0.809 & -6.82 & 1.156 & $<0.001$ & 0.264 \\
\hline & LSq & 63.81 & 57.59 & 1.096 & -6.23 & 1.033 & $<0.001$ & 0.593 \\
\hline
\end{tabular}

${ }^{1}$ Diets contained either $16.5 \% \mathrm{CP}$ for adequate MP (ADMP) or $14.6 \% \mathrm{CP}$ for low MP (LOMP).

${ }^{2}$ Least squares means were covariately adjusted for initial production values measured during the 2 wk before feeding the treatment diets.

${ }^{3}$ Standard error of the difference.

${ }^{4}$ Interaction between diet and week, where week $=4,8,12$, and 16 and is equivalent to periods 1 to 4 in LSq.

${ }^{5} \mathrm{aNDF}_{\mathrm{OM}}=$ neutral detergent fiber determined with $\alpha$-amylase, $\mathrm{Na}_{2} \mathrm{SO}_{3}$, exclusive of ash. pdNDF $\mathrm{OM}_{\text {M }}=$ potentially digestible aNDF $\mathrm{OM}_{\text {M }}($ difference between $\mathrm{aNDF}_{\mathrm{OM}}$ and $\left.\mathrm{iNDF}_{\mathrm{OM}}\right) \cdot \mathrm{iNDF}_{\mathrm{OM}}=$ indigestible $\mathrm{aNDF}_{\mathrm{OM}}$ based on $12 \mathrm{~d}$ in the rumen.

continuous trials was also observed in the meta-analysis of Huhtanen and Hetta (2012), although the magnitude of the difference between designs was greater in this study than in that analysis. However, in the analysis of Huhtanen and Hetta (2012) there were no differential effects in milk fat yield between designs.

The magnitude of production responses in milk protein and especially fat yield and the lower variability in LSq resulted in lower $\mathrm{NE}_{\mathrm{L}}$ output for LOMP in LSq $(P$ $=0.008)$ where differences were not observed in RCBD $(P>0.40)$. Despite these differences between designs in milk $\mathrm{NE}_{\mathrm{L}}$ output and no differences between diets or designs in DMI, feed efficiency $\left(\mathrm{NE}_{\mathrm{L}} / \mathrm{DMI}\right.$, Mcal/ $\mathrm{kg}$ ) was significantly lower in LOMP than in ADMP in both designs (Supplemental Figure S5; https://doi.org/ 10.3168/jds.2018-15730). In contrast, N use efficiency (NUE; milk protein $\mathrm{N} / \mathrm{N}$ intake, $\mathrm{g} / \mathrm{g}$ ) was higher in LOMP than ADMP, but this difference reached statistical significance only in LSq. Reducing dietary $\mathrm{N}$ is one of the most recognized and repeatable means by which to increase NUE (Huhtanen and Hristov, 2009; Powell et al., 2010; Lee et al., 2012b). However, from a practical standpoint, the improvement in NUE must be balanced against reduced milk protein production and potentially reduced feed efficiency (Zanton, 2016), although the joint effects of MP intake on feed and N efficiency are not very consistent (Phuong et al., 2013) and are likely dependent on changes in DMI and milk fat yield, which are more variable than the responses in $\mathrm{N}$ intake and milk protein yield.

\section{Digestibility and Metabolic Responses}

Intake of OM was not affected by diet irrespective of design; however, intake of $\mathrm{CP}$ and NDF was different between diets irrespective of design as intended (Table 5). Diet $\times$ week interactions for intake of chemical components were observed, which was consistent with that observed for DMI where intake for LOMP was lower than ADMP for periods 1 to 3, with differences disappearing during period 4 (Figure 1). Organic matter and $\mathrm{CP}$ apparent digestibility were reduced for LOMP in both designs, whereas NDF and potentially digestible NDF digestibility was reduced for LOMP in LSq only. Many studies have shown that decreasing $\mathrm{CP}$ concentration in the diet decreases $\mathrm{CP}$ apparent digestibility (Broderick, 2003; Weiss et al., 2009; Lee et al., 2012b), and this effect is likely due to the dilution of endogenous fecal protein (Moran and Vercoe, 1972). Lower NDF digestibility with lower CP is also often observed (Broderick, 2003; Colmenero and Broderick, 2006; Lee et al., 2012b), although not always (Weiss et al., 2009). A typical recommendation for the time required for dietary adaptation for representative changes in digestibility is 7 to $14 \mathrm{~d}$ (Schneider and Flatt, 1975). There was no diet $\times$ time interaction for digestibility 
measurements (Table 5); however, different inferences arose for NDF when LSq was the experimental design compared with RCBD, with the former resulting in a larger response than the latter with a smaller standard error. When potentially digestible NDF digestibility was evaluated, LOMP tended to have reduced digestibility compared with ADMP in $\operatorname{RCBD}(P=0.054)$. Whether changes in the fibrolytic microbial population occur over a more prolonged timeframe than has typically been assumed is not known. Weimer et al. (2010) showed that cows require $63 \mathrm{~d}$ to revert to pre-exchange microbial communities upon near-total exchange of ruminal contents, although ruminal chemistry parameters reverted to pre-exchange values within a few days. More recent work by Weimer et al. (2017) showed that microbial communities resembled pre-exchange communities after only $10 \mathrm{~d}$. When evaluating dietary changes, results from Machado et al. (2016) indicate that ruminal fermentation and microbial community composition stabilized after a maximum of $11 \mathrm{~d}$. Likewise, Rico et al. (2015) observed that ruminal microbial populations responded rapidly to dietary changes between milk fat inducing and recovery diets. These results indicate that the time allowed during this study for ruminal microbial population changes should have been sufficient for a complete adaptation between diets and that the discrepancy between designs is more a reflection of higher between-animal variability for RCBD and higher statistical power for LSq.

Nitrogen responses to the different diets and designs are shown in Table 6. As intended, cows fed LOMP had lower $\mathrm{N}$ intake than cows fed ADMP, which resulted in lower urine $\mathrm{N}$, milk $\mathrm{N}$, urine urea $\mathrm{N}$ (UUN), and MUN excretion for LOMP, and these inferences were unaffected by design. Urea clearance, UUN:PUN ratio, or UUN:urine $\mathrm{N}$ ratio were lower for cows fed LOMP than for those fed ADMP, and these inferences were not affected by design. Fecal $\mathrm{N}$ was not different between diets. These combined measurements resulted in higher residual $\mathrm{N}$ in ADMP than in LOMP, although this was significant only in LSq $(P<0.031)$ and did not differ from zero for either design. The primary route of excess $\mathrm{N}$ excretion is through urinary urea excretion (Spek et al., 2013), and changes in $\mathrm{N}$ excretion through this pathway would be expected to be fairly rapid unless a change in $\mathrm{N}$ partitioning to or from body protein pools occurred (Paquay et al., 1972). Biddle et al. (1975a,b) fed growing steers diets with $6 \% \mathrm{CP}$ to deplete the so-called labile $\mathrm{N}$ reserves for $5 \mathrm{wk}$ and observed that urinary $\mathrm{N}$ excretion was minimized by 3 wk after the diet change. When the diet changed to a higher $\mathrm{CP}$ recovery diet, the growing steers reached the point of maximum urinary $\mathrm{N}$ after $2 \mathrm{wk}$ on this new diet but ultimately continued on a pattern of decline after these initial 2 wk. In growing ruminants postruminally infused with different amounts of protein, changes in $\mathrm{N}$ excretion and retention have been very rapid, typically stabilizing in less than 1 wk (Hovell et al., 1987; Liu et al., 1995; Schroeder et al., 2006). Based on these data and the results in the literature, $\mathrm{N}$ partitioning measured in ruminants responds rapidly to changes in MP level, and the inferences were generally unaffected by experimental design with lactating dairy cows in this study, although the residual $\mathrm{N}$ response differed in magnitude between designs.

Plasma metabolites and insulin are shown in Table 7. As expected, cows fed LOMP had lower PUN compared with ADMP, and these inferences were consistent between designs. As was previously indicated, BUN concentration responded rapidly to changing dietary conditions (Lewis, 1957; Annison et al., 1959). The concentrations of PUN observed in this study were higher than those observed at similar concentrations of $\mathrm{CP}$ in previous studies (Colmenero and Broderick, 2006; Lee et al., 2012b) and what would be predicted based on MUN concentration (Broderick and Clayton, 1997). The reason for this discrepancy is not apparent. Glucose and NEFA were not affected by treatment and had similar levels across designs. Insulin concentration was numerically lower for both designs when cows were fed LOMP; however, this response was significant only for LSq $(P<0.025)$. There was very weak evidence for a carryover effect of previous treatment for NEFA $(P<0.09)$ and insulin $(P<0.17)$. Plasma NEFA concentration was lower and insulin was higher when the previous treatment was LOMP than when the previous treatment was ADMP. This response would tend to indicate that cows previously fed LOMP were in an anabolic state and partitioning fat toward tissues that would be insulin responsive in the subsequent period compared with cows previously fed ADMP. However, this interpretation is not consistent with the greater milk fat concentration or yield for cows previously fed LOMP, which tends to be reduced in periods of higher insulin concentration (Griinari et al., 1997). Nevertheless, these plasma carryover responses are not significant but could be monitored or tested directly in future experiments related to MP nutritional history.

\section{Overall Design Effects}

Within the range of dietary protein changes made in this experiment, previous meta-analyses did not detect differences between experimental designs (Huhtanen and Hetta, 2012; Zanton, 2016). However, milk fat concentration tended to differ between designs in the former analysis, and different milk production and feed efficiency responses were observed at higher levels of 
Table 6. Effect of protein concentration ${ }^{1}$ and experimental design on least squares means ${ }^{2}$ of $\mathrm{N}$ distribution in dairy cows fed according to a Latin square design (LSq) or a randomized complete block design (RCBD)

\begin{tabular}{|c|c|c|c|c|c|c|c|c|}
\hline \multirow[b]{2}{*}{ Item $^{3}$} & \multirow[b]{2}{*}{ Design } & \multicolumn{2}{|c|}{ Diet } & \multirow[b]{2}{*}{ SEM } & \multirow[b]{2}{*}{ Difference } & \multirow[b]{2}{*}{$\mathrm{SED}^{4}$} & \multicolumn{2}{|c|}{$P$-value } \\
\hline & & ADMP & LOMP & & & & Diet & Diet $\times$ week $^{5}$ \\
\hline \multirow[t]{2}{*}{ Intake $\mathrm{N}, \mathrm{g} / \mathrm{d}$} & RCBD & 779 & 720 & 16.2 & -59 & 22.5 & 0.016 & 0.007 \\
\hline & $\mathrm{LSq}$ & 812 & 731 & 12.6 & -80 & 13.3 & $<0.001$ & 0.971 \\
\hline \multirow[t]{2}{*}{ Fecal N, g/d } & RCBD & 282 & 306 & 9.9 & 25 & 14.6 & 0.105 & 0.733 \\
\hline & $\mathrm{LSq}$ & 293 & 310 & 12.6 & 18 & 9.8 & 0.088 & 0.655 \\
\hline \multirow[t]{2}{*}{ Urine $\mathrm{N}, \mathrm{g} / \mathrm{d}$} & $\mathrm{RCBD}$ & 238 & 187 & 7.9 & -51 & 10.7 & $<0.001$ & 0.867 \\
\hline & $\mathrm{LSq}$ & 230 & 182 & 10.1 & -47 & 9.3 & $<0.001$ & 0.928 \\
\hline \multirow[t]{2}{*}{ Urinary urea N, g/d } & RCBD & 181 & 104 & 6.1 & -77 & 8.4 & $<0.001$ & 0.011 \\
\hline & $\mathrm{LSq}$ & 176 & 100 & 6.8 & -76 & 6.6 & $<0.001$ & 0.288 \\
\hline \multirow{2}{*}{ Milk protein N, g/d } & RCBD & 254 & 242 & 3.2 & -12 & 4.3 & 0.011 & 0.527 \\
\hline & $\mathrm{LSq}$ & 257 & 240 & 5.0 & -17 & 3.9 & $<0.001$ & 0.799 \\
\hline \multirow{2}{*}{ MUN, g/d } & RCBD & 4.74 & 3.17 & 0.181 & -1.57 & 0.247 & $<0.001$ & 0.007 \\
\hline & $\mathrm{LSq}$ & 4.76 & 3.31 & 0.138 & -1.45 & 0.119 & $<0.001$ & 0.208 \\
\hline \multirow[t]{2}{*}{ Residual N, g/d } & RCBD & 0.2 & -14.9 & 8.43 & -15.0 & 11.42 & 0.201 & 0.181 \\
\hline & $\mathrm{LSq}$ & 24.2 & -8.1 & 14.98 & -32.3 & 14.00 & 0.031 & 0.894 \\
\hline \multirow[t]{2}{*}{ UUN/urine N, \% } & RCBD & 76.17 & 56.82 & 1.522 & -19.35 & 2.069 & $<0.001$ & 0.352 \\
\hline & $\mathrm{LSq}$ & 77.93 & 56.84 & 1.849 & -21.09 & 2.258 & $<0.001$ & 0.025 \\
\hline \multirow[t]{2}{*}{ UUN/PUN } & RCBD & 24.4 & 19.3 & 1.04 & -5.2 & 1.41 & 0.001 & 0.344 \\
\hline & $\mathrm{LSq}$ & 25.1 & 17.3 & 0.83 & -7.8 & 1.03 & $<0.001$ & 0.766 \\
\hline \multirow[t]{2}{*}{ Urea N clearance, L/h } & RCBD & 31.8 & 24.8 & 1.16 & -7.1 & 1.57 & $<0.001$ & 0.241 \\
\hline & $\mathrm{LSq}$ & 32.6 & 23.8 & 1.19 & -8.8 & 0.99 & $<0.001$ & 0.284 \\
\hline
\end{tabular}

${ }^{1}$ Diets contained either $16.5 \% \mathrm{CP}$ for adequate MP (ADMP) or $14.6 \% \mathrm{CP}$ for low MP (LOMP).

${ }^{2}$ Least squares means were covariately adjusted for initial production values measured during the 2 wk before feeding the treatment diets.

${ }^{3} \mathrm{UUN}=$ urine urea $\mathrm{N} ; \mathrm{PUN}=$ plasma urea $\mathrm{N}$.

${ }^{4}$ Standard error of the difference.

${ }^{5}$ Interaction between diet and week, where week $=4,8,12$, and 16 and is equivalent to period 1 to 4 in LSq.

$\mathrm{CP}$ in the latter analysis. A critical weakness of both of these analyses was that cows in continuous studies had lower DIM than cows in changeover trials. To address this weakness, this study was conducted using a common population of cows fed different levels of MP and studied under common management and experimental conditions using LSq and RCBD experimental designs.
A graphical depiction of the inferences relative to the null hypothesis of no treatment difference is shown in Figure 2A. Overall, there is close concordance (concordance correlation coefficient $=0.83$ ) and a strong relationship $\left(\mathrm{R}^{2}=0.84\right)$ between $t$-scores for LSq and RCBD. As discussed previously, there are several instances where the inference from LSq would yield a

Table 7. Effect of protein concentration ${ }^{1}$ and experimental design on least squares means ${ }^{2}$ of plasma measurements in dairy cows fed according to a Latin square design (LSq) or a randomized complete block design (RCBD)

\begin{tabular}{|c|c|c|c|c|c|c|c|c|}
\hline \multirow[b]{2}{*}{ Item $^{3}$} & \multirow[b]{2}{*}{ Design } & \multicolumn{2}{|c|}{ Diet } & \multirow[b]{2}{*}{ SEM } & \multirow[b]{2}{*}{ Difference } & \multirow[b]{2}{*}{$\mathrm{SED}^{4}$} & \multicolumn{2}{|c|}{$P$-value } \\
\hline & & ADMP & LOMP & & & & Diet & Diet $\times$ week $^{5}$ \\
\hline \multirow[t]{2}{*}{ PUN, mg/dL } & RCBD & 24.05 & 17.71 & 0.613 & -6.34 & 0.839 & $<0.001$ & 0.312 \\
\hline & $\mathrm{LSq}$ & 23.06 & 17.92 & 0.631 & -5.14 & 0.791 & $<0.001$ & 0.316 \\
\hline \multirow[t]{2}{*}{ Glucose, $\mathrm{m} M$} & RCBD & 3.09 & 3.05 & 0.060 & -0.04 & 0.081 & 0.637 & 0.080 \\
\hline & $\mathrm{LSq}$ & 3.03 & 3.07 & 0.077 & 0.03 & 0.059 & 0.564 & 0.045 \\
\hline \multirow{2}{*}{$\mathrm{NEFA}^{6}{ }^{6} \mu M$} & RCBD & 139.63 & 140.57 & 5.722 & 0.94 & 7.768 & 0.905 & 0.608 \\
\hline & $\mathrm{LSq}$ & 145.68 & 145.99 & 3.345 & 0.31 & 5.913 & 0.959 & 0.013 \\
\hline \multirow[t]{2}{*}{ Insulin, p $M$} & RCBD & 118.91 & 105.31 & 7.808 & -13.60 & 10.996 & 0.229 & 0.203 \\
\hline & $\mathrm{LSq}$ & 129.09 & 102.85 & 8.662 & -26.25 & 10.916 & 0.025 & 0.278 \\
\hline
\end{tabular}

${ }^{1}$ Diets contained either $16.5 \%$ CP for adequate MP (ADMP) or $14.6 \%$ CP for low MP (LOMP).

${ }^{2}$ Least squares means were covariately adjusted for initial production values measured during the 2 wk before feeding the treatment diets.

${ }^{3} \mathrm{PUN}=$ plasma urea $\mathrm{N} ; \mathrm{NEFA}=$ nonesterified fatty acids.

${ }^{4}$ Standard error of the difference.

${ }^{5}$ Interaction between diet and week, where week $=4,8,12$, and 16 and is equivalent to periods 1 to 4 in LSq.

${ }^{6}$ Carryover effect of previous treatment approached significant $(P<0.09)$ when design was LSq. 
rejection of the null hypothesis of no effect on the basis of $P<0.05$, whereas the test for RCBD was not rejected based on these data. There were no instances in which the inferences about treatment effects were reversed in LSq compared with RCBD. Therefore, LSq provided stronger evidence against the null hypothesis than RCBD when LOMP is estimated to be lower than ADMP; however, the direction and significance of the inference would not be affected. Only in the case of milk fat concentration was the inference for RCBD to reject the null hypothesis where the LSq null hypothesis could not be rejected on the basis of $P<0.05$. Overall, these responses highlight the capability of LSq to detect smaller differences than RCBD due to making within-cow comparisons in LSq. This would be the expectation if responses in LSq replicated treatment responses observed when diets were fed for a longer duration as in RCBD.

Although the statistical tests of the data are necessary for understanding the strength of the evidence for the hypothesized model, they are not sufficient because the magnitude of the responses is required to make a nutritional or management decision. Figure 2B shows the relationship between LSq and RCBD for the relative responses between LOMP and ADMP least squares means: $(\mathrm{LOMP}-\mathrm{ADMP}) /[0.5 \times(\mathrm{ADMP}+$ LOMP)]. Body weight change and residual $\mathrm{N}$ resulted in a large and opposite response when estimated within the different designs; for clarity, these results are excluded from the following discussion but are addressed later. Overall, there is close concordance between the numerical results of LSq and RCBD relative differences (concordance correlation coefficient $=0.97$ ). The results from Figure 2B are shown as a Bland-Altman plot (Bland and Altman, 1986) in Figure 2C along with the mean bias and the upper and lower limits of agreement between designs. There was no detectable slope bias between designs $(P>0.50)$; however, there was significant negative mean bias, indicating that over all of the responses measured in this study, the relative response observed in LSq was 1.84 percentage unit lower than the relative response observed in $\mathrm{RCBD}(P<0.026)$. A few specific responses stand out with the relative response estimated to be lower in LSq than in RCBD: milk fat percentage, insulin concentration, and the UUN:PUN ratio. The nature of these individual responses between designs and the large opposite responses for BW change could be reflective of continued alteration in energy partitioning after a shorter time on treatment when changing between diets compared with when fed the same diets continuously, although most responses show reasonably good agreement between designs.

This experiment was designed to have treatment responses as extreme as practically relevant. Therefore, the results of this study are limited to these extreme treatment differences, and an extrapolation to a scenario of lower treatment differences must be done with extreme caution. The reason for designing the diets to have extreme treatment responses was 2-fold: (1) there had to be treatment differences to be able to understand whether the inferences from this experiment are affected by design, and (2) this is where previous metaanalyses have shown these designs to yield different inferences (Huhtanen and Hetta, 2012; Zanton, 2016). The inferences of these meta-analyses were based on many experiments with different objectives, diets, sampling intensities, cow DIM, and so on. This study was conducted to directly test the effect of experimental design with animal characteristics, diets, and sampling that were the same between designs. The consistency of the conclusions from this study and those of the metaanalyses under hypothesized extreme treatment differences strengthens the inferences of the meta-analyses under situations of lower treatment differences that cover a greater inferential space.

\section{CONCLUSIONS}

In this experiment, where MP concentration was formulated to promote large treatment differences, diets resulted in different levels of production and $\mathrm{N}$ metabolism that were consistent with literature responses in both direction and magnitude. Under the conditions of this experiment with multiparous early-lactation cows fed diets with different levels of MP, the majority of response variables measured for $\mathrm{N}$ metabolism, digestibility, and production responses were not affected by experimental design. Treatment responses that may respond differently over time (e.g., DMI in this study) and that represent altered nutrient partitioning (e.g., BW change and residual $\mathrm{N}$ in this study) will likely not be reflected in short changeover designs. Milk fat yield and percentage responses were affected by previous treatment carryover in LSq. Collectively, it is concluded that most responses to differences in MP are consistent between LSq and RCBD; however, differing responses in energetic variables require further investigation.

\section{ACKNOWLEDGMENTS}

This work was supported by funding from the USDA Agricultural Research Service (Washington, DC) under National Program 101 Food Animal Production. The conscientious work of Kurt Pickar in feeding the cows, the rest of the farm staff in caring for the cows at the Dairy Forage Research Center Farm (Prairie du Sac, WI), and Wendy Radloff and Mary Becker (USDA Agricultural Research Service, Madison, WI) in conduct- 
A.

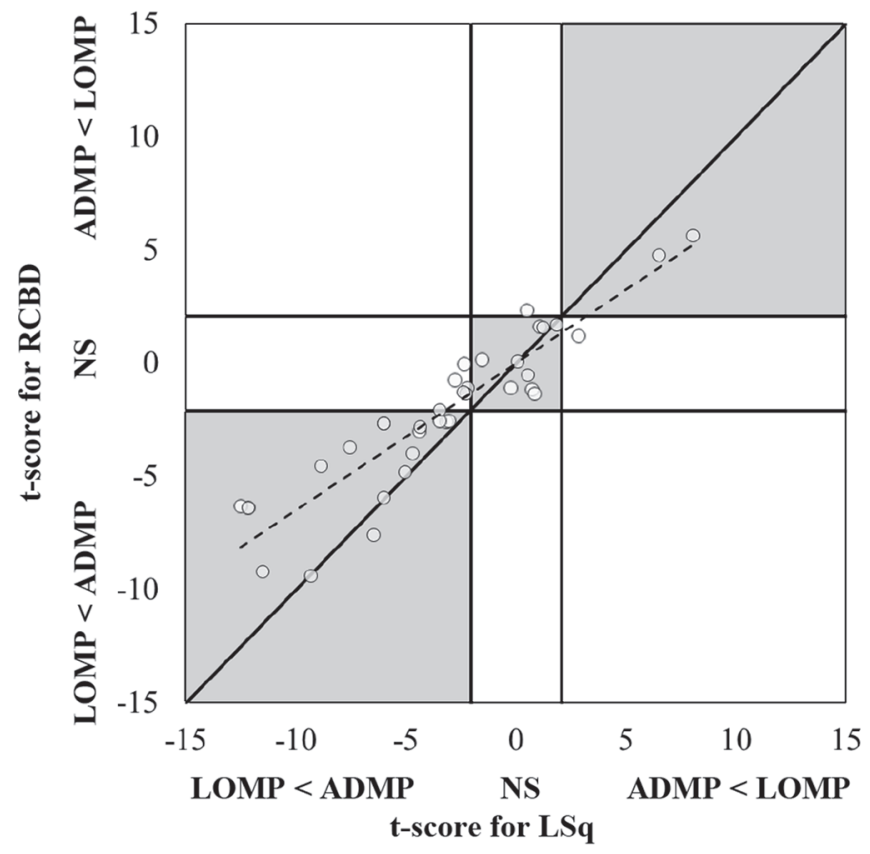

B.

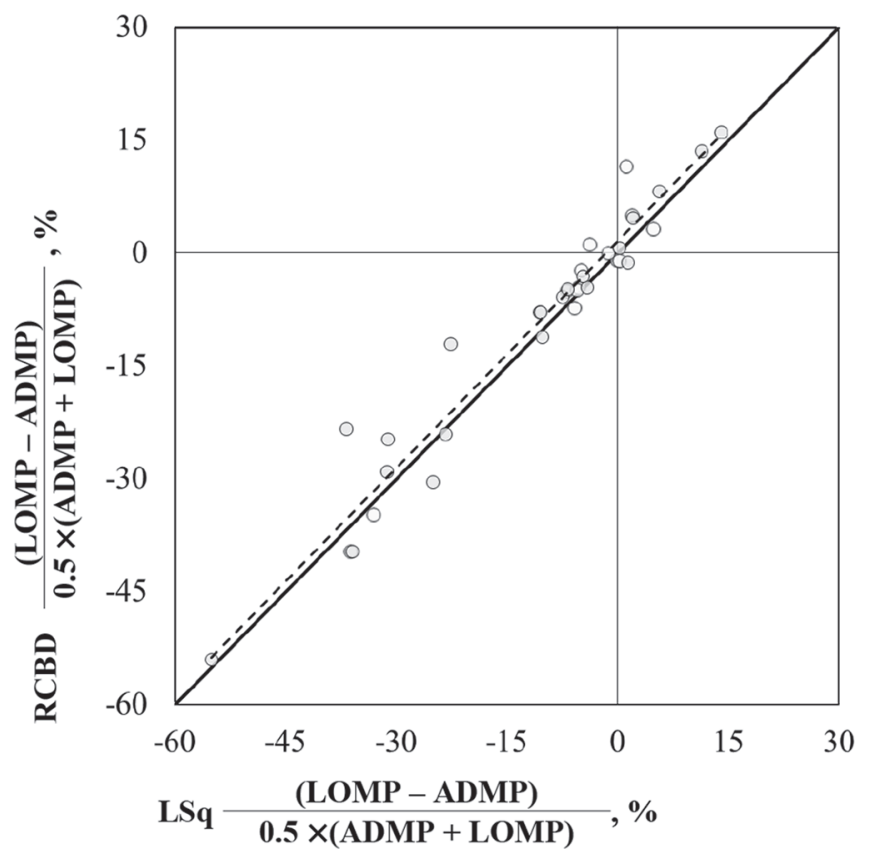

C.

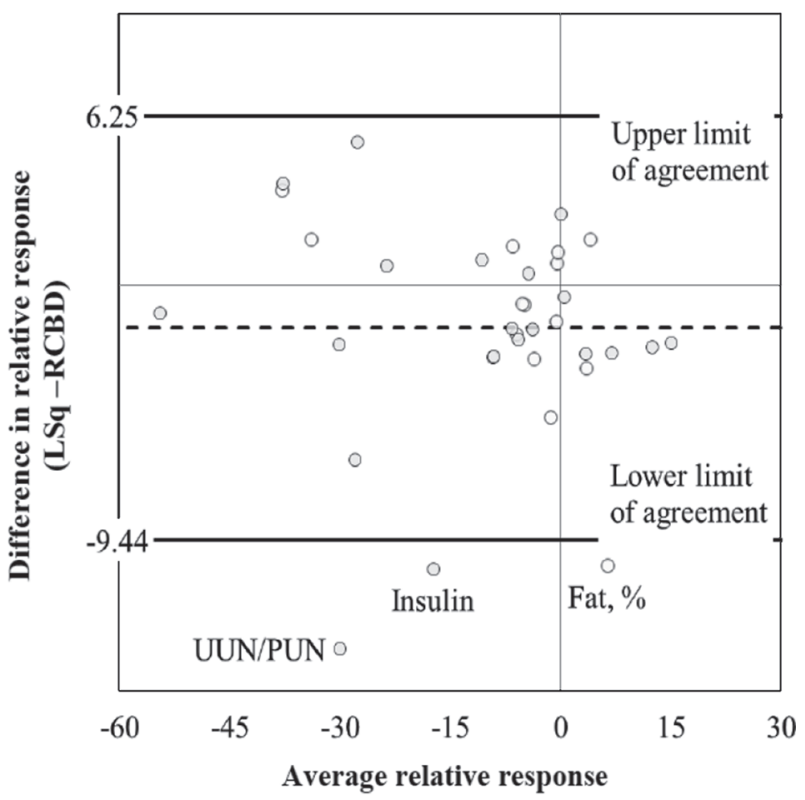

Figure 2. (A) Inference graph for differences between low MP (LOMP) and adequate MP (ADMP). Values for $t$-scores where $P<0.05$ are shown as the vertical and horizontal lines; values more extreme than these cutoffs indicate statistical significance under the threshold defined in this experiment. Values lying within the shaded sections represent making the same inference about the direction of the treatment response across designs. Dashed line is the best fit linear response: randomized complete block design $(\mathrm{RCBD})=0.021(0.274)+0.65(0.047) \times$ Latin square design $(\mathrm{LSq}) ; \mathrm{R}^{2}=0.84$. Diagonal line is $\mathrm{y}=\mathrm{x}$; concordance correlation coefficient (95\% CI in parentheses) $=0.83(0.738,0.897)$. (B) Relative response between LOMP and ADMP LSM. For clarity, the values for BW change and residual N are not shown, which had the coordinates $(-46.87,60.99)$ and $(205.44,-401.24)$, respectively. Dashed line is the best fit linear response exclusive of BW change and residual N: $\mathrm{RCBD}=1.55(0.814)+1.00(0.043) \times \mathrm{LSq} ; \mathrm{R}^{2}=0.94$. Diagonal line is $\mathrm{y}=\mathrm{x}$; concordance correlation coefficient $(95 \% \mathrm{CI}$ in parentheses $)=$ $0.97(0.934,0.982)$. (C) Difference plots for the relative response between LOMP and ADMP LSM without the response in BW change (108.87, $7.06)$ and residual $\mathrm{N}(-606.68,-97.90)$. Slope bias was not detected $(P>0.50)$; mean bias $(95 \%$ CI in parentheses $)=-1.84(-0.24,-3.46)$ was significant (dashed line; $P<0.026$ ). The limits of agreement (mean bias $\pm 2 \times \mathrm{SD}$ ) ranged from -9.44 to 6.25 . UUN $=$ urine urea $\mathrm{N} ; \mathrm{PUN}$ $=$ plasma urea $\mathrm{N}$. 
ing the laboratory analyses is gratefully acknowledged. Mention of any trademark or proprietary product in this paper does not constitute a guarantee or warranty of the product by the USDA or the Agricultural Research Service and does not imply its approval to the exclusion of other products that also may be suitable.

\section{REFERENCES}

Allen, M. S. 2000. Effects of diet on short-term regulation of feed intake by lactating dairy cattle. J. Dairy Sci. 83:1598-1624. https:// doi.org/10.3168/jds.S0022-0302(00)75030-2.

Annison, E. F., D. Lewis, and D. B. Lindsay. 1959. The metabolic changes which occur in sheep transferred to lush spring grass. I. Changes in blood and rumen constituents. J. Agric. Sci. 53:34-41. https://doi.org/10.1017/S0021859600030896.

AOAC. 1990. Official Methods of Analysis. 15th ed. Association of Official Analytical Chemists, Arlington, VA.

Barros, T., M. A. Quaassdorff, M. J. Aguerre, J. J. O. Colmenero, S. J. Bertics, P. M. Crump, and M. A. Wattiaux. 2017. Effects of dietary crude protein concentration on late-lactation dairy cow performance and indicators of nitrogen utilization. J. Dairy Sci. 100:5434-5448. https://doi.org/10.3168/jds.2016-11917.

Benefield, B. C., R. A. Patton, M. J. Stevenson, and T. R. Overton. 2009. Evaluation of rumen-protected methionine sources and period length on performance of lactating dairy cows within Latin squares. J. Dairy Sci. 92:4448-4455. https://doi.org/10.3168/jds $.2008-1275$.

Biddle, G. N., J. L. Evans, and J. R. Trout. 1975a. Labile nitrogen reserves and plasma nitrogen fractions in growing cattle. J. Nutr. 105:1584-1591. https://doi.org/10.1093/jn/105.12.1584.

Biddle, G. N., J. L. Evans, and J. R. Trout. 1975b. Labile nitrogen reserves in the ruminant. Metabolic changes in growing cattle employing a nitrogen depletion-repletion treatment. J. Nutr. 105:1578-1583. https://doi.org/10.1093/jn/105.12.1578.

Bland, J. M., and D. G. Altman. 1986. Statistical methods for assessing agreement between two methods of clinical measurement. Lancet 1(8476):307-310. https://doi.org/10.1016/S0140-6736(86)90837-8.

Broderick, G. A. 2003. Effects of varying dietary protein and energy levels on the production of lactating dairy cows. J. Dairy Sci. 86:1370-1381. https://doi.org/10.3168/jds.S0022-0302(03)73721 -7 .

Broderick, G. A., and M. K. Clayton. 1997. A statistical evaluation of animal and nutritional factors influencing concentrations of milk urea nitrogen. J. Dairy Sci. 80:2964-2971. https://doi.org/10 .3168/jds.S0022-0302(97)76262-3.

Broderick, G. A., T. Kowalczyk, and L. D. Satter. 1970. Milk production response to supplementation with encapsulated methionine per os or casein per abomasum. J. Dairy Sci. 53:1714-1721. https: //doi.org/10.3168/jds.S0022-0302(70)86468-2.

Cochran, W. G., K. M. Autrey, and C. Y. Cannon. 1941. A double change-over design for dairy cattle feeding experiments. J. Dairy Sci. 24:937-951. https://doi.org/10.3168/jds.S0022-0302(41)95480 -2 .

Colmenero, J. J. O., and G. A. Broderick. 2006. Effect of dietary crude protein concentration on milk production and nitrogen utilization in lactating dairy cows. J. Dairy Sci. 89:1704-1712. https://doi .org/10.3168/jds.S0022-0302(06)72238-X.

Ferraretto, L. F., H. Gencoglu, K. S. Hackbart, A. B. Nascimento, F. Dalla Costa, R. W. Bender, J. N. Guenther, R. D. Shaver, and M. C. Wiltbank. 2014. Effect of feed restriction on reproductive and metabolic hormones in dairy cows. J. Dairy Sci. 97:754-763. https: //doi.org/10.3168/jds.2013-6925.

Ferrell, C. L., L. J. Koong, and J. A. Nienaber. 1986. Effect of previous nutrition on body composition and maintenance energy costs of growing lambs. Br. J. Nutr. 56:595-605. https://doi.org/10.1079/ BJN19860140.

Giallongo, F., M. T. Harper, J. Oh, J. C. Lopes, H. Lapierre, R. A. Patton, C. Parys, I. Shinzato, and A. N. Hristov. 2016. Effects of rumen-protected methionine, lysine, and histidine on lactation performance of dairy cows. J. Dairy Sci. 99:4437-4452. https://doi .org/10.3168/jds.2015-10822.

Griinari, J. M., M. A. McGuire, D. A. Dwyer, D. E. Bauman, and D. L. Palmquist. 1997. Role of insulin in the regulation of milk fat synthesis in dairy cows. J. Dairy Sci. 80:1076-1084. https://doi .org/10.3168/jds.S0022-0302(97)76032-6.

Gross, J., H. A. van Dorland, R. M. Bruckmaier, and F. J. Schwarz. 2011. Performance and metabolic profile of dairy cows during a lactational and deliberately induced negative energy balance with subsequent realimentation. J. Dairy Sci. 94:1820-1830. https://doi .org/10.3168/jds.2010-3707.

Gustafsson, A. H., and D. L. Palmquist. 1993. Diurnal variation of rumen ammonia, serum urea, and milk urea in dairy cows at high and low yields. J. Dairy Sci. 76:475-484. https://doi.org/10.3168/ jds.S0022-0302(93)77368-3.

Hovell, F. D. D., E. R. Ørskov, D. J. Kyle, and N. A. MacLeod. 1987. Undernutrition in sheep. Nitrogen repletion by N-depleted sheep. Br. J. Nutr. 57:77-88. https://doi.org/10.1079/BJN19870011.

Hristov, A. N., M. Harper, J. Oh, F. Giallongo, J. C. Lopes, G. Cudoc, J. Clay, R. Ward, and L. E. Chase. 2018. Short communication: Variability in milk urea nitrogen and dairy total mixed ration composition in the northeastern United States. J. Dairy Sci. 101:1579-1584. https://doi.org/10.3168/jds.2017-12925.

Huhtanen, P., and M. Hetta. 2012. Comparison of feed intake and milk production responses in continuous and change-over design dairy cow experiments. Livest. Sci. 143:184-194. https://doi.org/ 10.1016/j.livsci.2011.09.012.

Huhtanen, P., and A. N. Hristov. 2009. A meta-analysis of the effects of dietary protein concentration and degradability on milk protein yield and milk N efficiency in dairy cows. J. Dairy Sci. 92:32223232. https://doi.org/10.3168/jds.2008-1352.

Jones, B., and M. G. Kenward. 2003. Design and Analysis of CrossOver Trials. 2nd ed. Chapman and Hall/CRC, London, UK.

Law, R. A., F. J. Young, D. C. Patterson, D. J. Kilpatrick, A. R. G. Wylie, and C. S. Mayne. 2009. Effect of dietary protein content on animal production and blood metabolites of dairy cows during lactation. J. Dairy Sci. 92:1001-1012. https://doi.org/10.3168/jds .2008-1155.

Lee, C., F. Giallongo, A. N. Hristov, H. Lapierre, T. W. Cassidy, K. S. Heyler, G. A. Varga, and C. Parys. 2015. Effect of dietary protein level and rumen-protected amino acid supplementation on amino acid utilization for milk protein in lactating dairy cows. J. Dairy Sci. 98:1885-1902. https://doi.org/10.3168/jds.2014-8496.

Lee, C., A. N. Hristov, T. W. Cassidy, K. S. Heyler, H. Lapierre, G. A. Varga, M. J. de Veth, R. A. Patton, and C. Parys. 2012a. Rumenprotected lysine, methionine, and histidine increase milk protein yield in dairy cows fed a metabolizable protein-deficient diet. J. Dairy Sci. 95:6042-6056. https://doi.org/10.3168/jds.2012-5581.

Lee, C., A. N. Hristov, K. S. Heyler, T. W. Cassidy, H. Lapierre, G. A. Varga, and C. Parys. 2012b. Effects of metabolizable protein supply and amino acid supplementation on nitrogen utilization, milk production, and ammonia emissions from manure in dairy cows. J. Dairy Sci. 95:5253-5268. https://doi.org/10.3168/jds.2012-5366.

Lewis, D. 1957. Blood-urea concentration in relation to protein utilization in the ruminant. J. Agric. Sci. 48:438-446. https://doi.org/10 .1017/S0021859600032962.

Lin, L. I.-K. 1989. A concordance correlation coefficient to evaluate reproducibility. Biometrics 45:255-268. https://doi.org/10.2307/ 2532051.

Liu, S. M., G. E. Lobley, N. A. Macleod, D. J. Kyle, X. B. Chen, and E. R. Ørskov. 1995. Effects of long-term protein excess or deficiency on whole-body protein turnover in sheep nourished by intragastric infusion of nutrients. Br. J. Nutr. 73:829-839. https:/ /doi.org/10.1079/BJN19950088.

Lucas, H. L. 1960. Critical features of good dairy feeding experiments. J. Dairy Sci. 43:193-212. https://doi.org/10.3168/jds.S0022 -0302(60)90142-9.

Machado, M. G., E. Detmann, H. C. Mantovani, S. C. Valadares Filho, C. B. P. Bento, M. I. Marcondes, and A. S. Assunção. 2016. Evaluation of the length of adaptation period for changeover and cross- 
over nutritional experiments with cattle fed tropical forage-based diets. Anim. Feed Sci. Technol. 222:132-148. https://doi.org/10 .1016/j.anifeedsci.2016.10.009.

Maldini, G., and M. S. Allen. 2018. Temporal effects of ruminal propionic acid infusion on feeding behavior of Holstein cows in the postpartum period. J. Dairy Sci. 101:3077-3084. https://doi.org/ $10.3168 /$ jds.2017-13857.

Martineau, R., D. R. Ouellet, E. Kebreab, and H. Lapierre. 2016. Casein infusion rate influences feed intake differently depending on metabolizable protein balance in dairy cows: A multilevel metaanalysis. J. Dairy Sci. 99:2748-2761. https://doi.org/10.3168/jds .2015-10427.

Metcalf, J. A., L. A. Crompton, D. Wray-Cahen, M. A. Lomax, J. D. Sutton, D. E. Beever, J. C. MacRae, B. J. Bequette, F. R. C Backwell, and G. E. Lobley. 1996. Responses in milk constituents to intravascular administration of two mixtures of amino acids to dairy cows. J. Dairy Sci. 79:1425-1429. https://doi.org/10.3168/ jds.S0022-0302(96)76500-1.

Metcalf, J. A., R. J. Mansbridge, J. S. Blake, J. D. Oldham, and J. R. Newbold. 2008. The efficiency of conversion of metabolisable protein into milk true protein over a range of metabolisable protein intakes. Animal 2:1193-1202. https://doi.org/10.1017/ S1751731108002140.

Moraes, L. E., E. Kebreab, J. L. Firkins, R. R. White, R. Martineau, and H. Lapierre. 2018. Predicting milk protein responses and the requirement of metabolizable protein by lactating dairy cows. J. Dairy Sci. 101:310-327. https://doi.org/10.3168/jds.2016-12507.

Moran, J. B., and J. E. Vercoe. 1972. Some factors affecting apparent nitrogen digestibility of roughage diets fed to cattle. J. Agric. Sci. 78:173-177. https://doi.org/10.1017/S0021859600068982.

NRC. 1971. A Guide to Environmental Research on Animals. National Academy of Science, Washington, D. C.

NRC. 2001. Nutrient Requirements of Dairy Cattle. National Academy Press, Washington, DC.

Oser, B. L. 1965. Hawk's Physiological Chemistry. 14th ed. McGrawHill, New York, NY.

Paquay, R., R. De Baere, and A. Lousse. 1972. The capacity of the mature cow to lose and recover nitrogen and the significance of protein reserves. Br. J. Nutr. 27:27-37. https://doi.org/10.1079/ BJN19720066.

Phuong, H. N., N. C. Friggens, I. J. M. de Boer, and P. Schmidely. 2013. Factors affecting energy and nitrogen efficiency of dairy cows: A meta-analysis. J. Dairy Sci. 96:7245-7259. https://doi .org/10.3168/jds.2013-6977.

Powell, J. M., C. J. P. Gourley, C. A. Rotz, and D. M. Weaver. 2010. Nitrogen use efficiency: A potential performance indicator and policy tool for dairy farms. Environ. Sci. Policy 13:217-228. https: //doi.org/10.1016/j.envsci.2010.03.007.

R Core Team. 2015. R: A Language and Environment for Statistical Computing. R Foundation for Statistical Computing, Vienna, Austria.

Rico, D. E., and K. J. Harvatine. 2013. Induction of and recovery from milk fat depression occurs progressively in dairy cows switched between diets that differ in fiber and oil concentration. J. Dairy Sci. 96:6621-6630. https://doi.org/10.3168/jds.2013-6820.

Rico, D. E., S. H. Preston, J. M. Risser, and K. J. Harvatine. 2015. Rapid changes in key ruminal microbial populations during the induction of and recovery from diet-induced milk fat depression in dairy cows. Br. J. Nutr. 114:358-367. https://doi.org/10.1017/ S0007114515001865.

SAS Institute. 2013. SAS User's Guide: Statistics. Version 9.4. SAS Inst. Inc., Cary, NC.

Schneider, B. H., and W. P. Flatt. 1975. The Evaluation of Feeds Through Digestibility Experiments. The University of Georgia Press, Athens.

Schroeder, G. F., E. C. Titgemeyer, M. S. Awawdeh, J. S. Smith, and D. P. Gnad. 2006. Effects of energy level on methionine utilization by growing steers. J. Anim. Sci. 84:1497-1504. https://doi.org/10 $.2527 / 2006.8461497 x$.

Spek, J. W., J. Dijkstra, G. van Duinkerken, W. H. Hendriks, and A. Bannink. 2013. Prediction of urinary nitrogen and urinary urea nitrogen excretion by lactating dairy cattle in northwestern Europe and North America: A meta-analysis. J. Dairy Sci. 96:4310-4322. https://doi.org/10.3168/jds.2012-6265.

St-Pierre, N. R., and J. T. Sylvester. 2005. Effects of 2-hydroxy4-(methylthio) butanoic acid (HMB) and its isopropyl ester on milk production and composition by Holstein cows. J. Dairy Sci. 88:2487-2497. https://doi.org/10.3168/jds.S0022-0302(05)72926 $-\mathrm{X}$.

Tebbe, A. W., and W. P. Weiss. 2018. Evaluation of creatinine as a urine marker and factors affecting urinary excretion of magnesium by dairy cows. J. Dairy Sci. 101:5020-5032. https://doi.org/ 10.3168/jds.2017-14098.

Valadares, R. F. D., G. A. Broderick, S. C. V. Filho, and M. K. Clayton. 1999. Effect of replacing alfalfa silage with high moisture corn on ruminal protein synthesis estimated from excretion of total purine derivatives. J. Dairy Sci. 82:2686-2696. https://doi.org/10 .3168/jds.S0022-0302(99)75525-6.

Weimer, P. J., M. S. Cox, T. V. de Paula, M. Lin, M. B. Hall, and G. Suen. 2017. Transient changes in milk production efficiency and bacterial community composition resulting from near-total exchange of ruminal contents between high- and low-efficiency Holstein cows. J. Dairy Sci. 100:7165-7182. https://doi.org/10.3168/ jds.2017-12746.

Weimer, P. J., D. M. Stevenson, H. C. Mantovani, and S. L. C. Man. 2010. Host specificity of the ruminal bacterial community in the dairy cow following near-total exchange of ruminal contents. J. Dairy Sci. 93:5902-5912. https://doi.org/10.3168/jds.2010-3500.

Weiss, W. P., N. R. St-Pierre, and L. B. Willett. 2009. Varying type of forage, concentration of metabolizable protein, and source of carbohydrate affects nutrient digestibility and production by dairy cows. J. Dairy Sci. 92:5595-5606. https://doi.org/10.3168/jds.2009 $-2247$.

Whitelaw, F. G., J. S. Milne, E. R. Ørskov, and J. S. Smith. 1986. The nitrogen and energy metabolism of lactating cows given abomasal infusions of casein. Br. J. Nutr. 55:537-556. https://doi.org/10 .1079/BJN19860061.

Wu, Z., and L. D. Satter. 2000. Milk production during the complete lactation of dairy cows fed diets containing different amounts of protein. J. Dairy Sci. 83:1042-1051. https://doi.org/10.3168/jds .S0022-0302(00)74968-X.

Zanton, G. I. 2016. Analysis of production responses to changing crude protein levels in lactating dairy cow diets when evaluated in continuous or change-over experimental designs. J. Dairy Sci. 99:4398-4410. https://doi.org/10.3168/jds.2015-10438. 